\title{
COMPARISON OF MICRODOSE GnRH AGONIST PROTOCOL WITH GnRH ANTAGONIST/LETRAZOLE PROTOCOL IN PATIENTS WITH POOR OVARIAN RESPONSE
}

\author{
Yigit CAKIROGLU, Sule Yildirim KOPUK, Orkun BASARIR, Serdar FILIZ, Birol VURAL \\ Kocaeli University School of Medicine, Clinical Center for Infertility, Kocaeli
}

\section{SUMMARY}

Objective: To compare microdose GnRH agonist (MDL) protocol with GnRH antagonist/letrazole (AL) protocol in patients with poor ovarian response.

Design: Randomised clinical trial.

Setting: Kocaeli University Assisted Reproductive Centre

Patients: Fifty-five patients with the diagnosis of poor ovarian response (POR) were randomized and performed either MDL or AL protocol.

Interventions: POR was diagnosed according to ESHRE Bologna criteria in case of presence of 2 out of 3 criteria. In the MDL group ( $n=27), 40 \mu \mathrm{g} / 0.2 \mathrm{cc}$ subcutaneous leuprolid acetate was given two times a day starting on the first day of menstrual cycle. On the second day of the cycle, gonadotrophin stimulation was started at 450-600 IU and/or 150 IU human menopausal gonadotrophin ( $h M G)$ along with leuprolid. In the AL group ( $n=28), 5 \mathrm{mg}$ letrazole was given for 5 days starting on the second day of the spontaneous cycle and after the 5th day of the cycle, 450-600 IU and/or 150 IU hMG was given.

Main Outcome Measures: To compare the outcomes of MDL protocol with AL protocol in patients with poor ovarian response.

Results: Stimulation days, total gonadotrophin dose (IU), peak E2 (pg/ml) levels, and endometrial thickness were found to be statistically significantly lower in the AL group. While no cases of cycle cancellation was detected in the MDL group, statistically significantly higher rates of cycle cancellation (\%42.8, $p<0.001)$ was detected in the AL group. No statistically significant differences were detected in total oocyte numbers (3.7 \pm 2.9 vs 2.7 \pm 2.2$)$, number of transferred embryos (1.4 \pm 0.5 vs 1.4 \pm 1.9$)$ and pregnancy rates (3 vs 2) in between the groups.

Comment: Although AL protocol is not superior to MDL protocol in poor ovarian response patients, it may be used as an alternative protocol.

Key words: letrazole, microdose, poor ovarian response

Journal of Turkish Society of Obstetrics and Gynecology, (J Turk Soc Obstet Gynecol), 2013; Vol: 10, Issue: 3, Pages: 132- 7

Address for Correspondence: Dr. Yiğit Çakıroğlu. Kocaeli Üniversitesi Tıp Fakültesi, Yardımla Üreme Teknikleri Merkezi, 41000 Kocaeli, Türkiye Phone: +90 (532) 5856588

e-mail: dryigit1@yahoo.com

Received: 12 November 2012, revised: 04 May 2013, accepted: 05 May 2013, online publication: 06 . May 2013 


\section{ZAYIF OVER YANITLI HASTALARDA MIKKRODOZ GnRH AGONIST PROTOKOL ILLE GnRH ANTAGONIST/LETRAZOL PROTOKOLUN KARŞILAŞTIRILMASI}

\section{ÖZET}

Objektif: Zaylf over yanttl hastalarda mikrodoz GnRH agonist (MDL) protokol ile GnRH antagonist/letrazol (AL) protokolunun karşılaş̧tırılması.

Planlama: Randomize klinik çalışma.

Ortam: Kocaeli Üniversitesi Tip Fakültesi Yardımla Üreme Merkezi.

Hastalar: Zaylf over yanitı (ZOY) tanisi konulan toplam 55 hasta rastgele randomize edilerek MDL ya da AL protokolu uygulandl.

Girişim: ZOY, ESHRE Bologna kriterlerine göre ü̧̧ kriterden ikisinin mevcut olması halinde konuldu. MDL grubunda

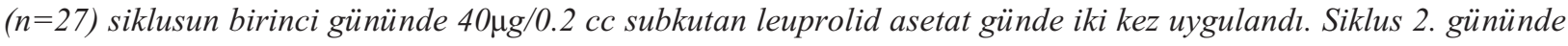
gonadotropin stimulasyonu 450-600 IU ve/veya 150 IU insan menapozal gonadotropin (hMG) leuprolid ile eş zamanls uygulandl. AL grubunda (n=28) spontan menstruasyonun 2. gününde $5 \mathrm{mg}$ letrazol 5 gün süre ile ve siklusun 5 . gününden itibaren gonadotropin stimulasyonu 450-600 IU ve/veya 150 IU hMG uygulandl.

Değerlendirme Parametreleri: Zaylf over yanttl hastalarda mikrodoz GnRH agonist (MDL) protokol ile GnRH antagonist/letrazol (AL) protokolunun sonuç larını karşılaşıtırmak.

Sonuç: Stimulasyon süresi, toplam gonadotropin dozu (IU), pik E2 ( $\mathrm{pg} / \mathrm{ml})$ ve OPU günü endometrial kalınlık AL grubunda istatistiksel anlamlı olarak daha düşük saptandl. MDL grubunda siklus iptali belirlenmezken, AL grubunda istatistiksel anlaml olarak daha fazla oranda (\%35.7, $p<0.001)$ siklus iptali belirlendi. Toplam oosit saylst (3.7 $\pm 2.9^{\prime} a$

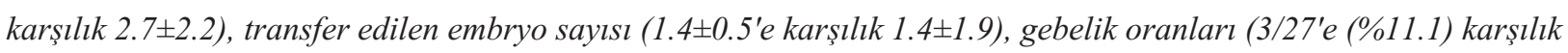
2/28 (\%7.1)) ve implantasyon oranları (3/36'e (\%8.3) karşıllı 2/22 (\%9.1)) arasinda istatistiksel anlamlı farklılık izlenmedi.

Yorum: Zaylf over yanıtlı hastalarda AL protokol, MDL protokole belirgin üstünlüğ̈̈ olmamasina karșllık alternatif olarak uygulanabilir.

Anahtar kelimeler: letrazol, mikrodoz, zaylf over yanitı

Türk Jinekoloji ve Obstetrik Derneği Dergisi, (J Turk Soc Obstet Gynecol), 2013; Cilt: 10, Sayl: 3, Sayfa: 132- 7

\section{INTRODUCTION}

Patients with the diagnosis of poor ovarian response (POR) are important group in Invitro fertilization center that the prevalance of poor ovarian response is 9 to $24 \%{ }^{(1)}$. POR was defined according to ESHRE Bologna criteria ${ }^{(2)}$.

There are many different stimulation regimens in POR but current protocols are not found to be superior than others ${ }^{(3-5)}$. Boost/ FSH regimen, microdose GnRH agonist protocol, stop GnRH agonist protocol, GnRH antagonist/letrazole protocol, agonist-antagonist protocol and co-treatment with GH or transdermal testosteron are reported similar pregnancy outcome ${ }^{6-}$ 8).

Letrazole is an aromatase inhibitor that inhibit the aromatization of androgens into estrogens; in this regard, the hypothalamic pituitary axis is released from the negative feedback leading to increased endogen gonadotropin secretion ${ }^{(9)}$. Letrazole causes an increase in intraovarian androgens and FSH receptor expression on granulosa cells that leading to augmentation of follicular sensitivity to $\mathrm{FSH}^{(10)}$.

Letrazole affects both ovary and endometrium $(11,12)$. It leads to formation of intraovarian hyperandrogenic media and FSH stimulation that increased number of retrieved oocytes and also increase endometrial receptivity by the means of inhibition of $\mathrm{P} 450$ endometrial aromatase enzyme. In this study, we aimed to compare microdose GnRH agonist (MDL) protocol with GnRH antagonist/letrazole (AL) protocol in patients with poor ovarian response. 


\section{MATERIAL AND METHOD}

This study was a prospective randomized controlled trial with 55 poor responders who were admitted to between September 2011 and July 2012. The study was approved by the local ethics committe. Written informed consent was obtained from each participant. Patients were randomly allocated to receive either Microdose $\mathrm{GnRH}$ agonist protocol or GnRH antagonit/letrazole protocol .Each patient choose a sealed envelope containing the randomized assignment to either one of the two protocols. Doctors and embryolog were not informed of the study group.

POR was diagnosed according to ESHRE Bologna criteria in case of presence of 2 out of 3 criteria (1): advanced maternal age ( $\geq 40$ years ) or any other risk factor for POR or the collection of less than four oocytes and cancelled cycle (following the development of less than three growing follicles) in response to at least 150 IU FSH per day or an abnormal ovarian reserve test $(\mathrm{AMH}<0.5-1.1 \mathrm{ng} / \mathrm{ml}$ or AFC $<5-7$ follicles. In MDL group ( $\mathrm{n}=27), 40 \mu \mathrm{g} / 0.2 \mathrm{cc}$ subcutaneous leuprolid acetate (Lucrin; Abbott, France) was given two times a day starting on the first day of menstrual cycle. On the second day of the cycle, gonadotropin stimulation was started at 450-600 IU ( randomized randomly Gonal F; Merck Serono, Switzerland or Puregon; MSD, Netherlands ) and/or 150 IU human menopausal gonadotrophin (hMG) (Menogon; Ferring, Germany) along with leuprolid. In AL group ( $\mathrm{n}=28), 5 \mathrm{mg}$ letrazole (Femara; Novartis, USA) was given for 5 days starting on the second day of the spontaneous cycle and 450$600 \mathrm{IU}$ and/ or $150 \mathrm{IU}$ hMG was given from the 5th day of the cycle on. When the dominant follicle reached a mean diameter of $14 \mathrm{~mm}$, cetrorelix or ganirellix 0.25 mg /d S.C (Cetrotide; Merck Serono, Switzerland or Orgalutron; MSD, Netherlands) was administered randomly.

Patients monitored with serum E2, LH, progesterone level and serial transvaginal ultrasonographic examinations. When at least 2 follicles reached a mean diameter of $18 \mathrm{~mm}$ or 3 or more follicles reached 17 $\mathrm{mm}, 250 \mathrm{mcg}$ recombinant chorigonadotrophin alfa (rHCG ) (Ovitrelle; Merck Serono, Switzerland) was applied. When one follicle reached more than $17 \mathrm{~mm}$ or serum progesteron level was $>1.5 \mathrm{ng} / \mathrm{ml}$ on $\mathrm{rHCG}$ day, cycle was cancelled.

Oocytes retrieval was carried out under transvaginal ultrasound-guided puncture 34-36 h after rHCG administration. Intracytoplasmic sperm injection (ICSI) was performed to all patients. Day 2 or 3 good quality embryos was transferred intrauterine cavity under ultrasound guidance. The luteal phase was supported by daily vaginal progesterone (Crinone gel $8 \%$; Merck Serono, Switzerland) starting on OPU day. After 1214 day of ET, when serum $\beta-H C G$ level was positive, the luteal phase was supported until 10 week of pregnancy or negative the luteal phase support was stopped. Clinical pregnacy was defined as the presence of an intrauterine fetal pole and fetal hearth activity in gestational sac.

The statistical analyses were performed using the SPSS 11.5 (SPSS INC., Chicago, IL, USA). Values were expressed as mean $\pm \mathrm{SD}$. $\mathrm{P} \leq 0.05$ was considered statistically significant.

\section{RESULTS}

Patients' features are compared in Table I. There were no significant differences between two groups regarding the mean female age, body mass index (BMI), FSH level on cycle day 3 , AMH level and number of previous failed IVF cycles.

Table 1: Comparison of patients characteristics in GnRH agonist (MDL) protocol versus GnRH antagonist/ letrazole (AL) protocol versus GnRH.

\begin{tabular}{llll}
\hline $\begin{array}{l}\text { Characteristics of } \\
\text { patients }\end{array}$ & $\begin{array}{l}\text { MDL } \\
(\mathbf{n = 2 7})\end{array}$ & $\begin{array}{l}\text { AL } \\
(\mathbf{n}=\mathbf{2 8})\end{array}$ & $\boldsymbol{P}$ \\
\hline Age $(\mathrm{yr})$ & $36.1 \pm 5.3$ & $34.4 \pm 5.4$ & 0.25 \\
BMI $\left(\mathrm{kg} /{ }^{2}\right)$ & $21.3 \pm 2.8$ & $24.7 \pm 4.4$ & 0.45 \\
Day 3 FSH $(\mathrm{mIU} / \mathrm{ml})$ & $11.4 \pm 6.2$ & $10.4 \pm 4.5$ & 0.52 \\
Day 3 LH (mIU/ml) & $6.0 \pm 2.8$ & $5.5 \pm 2.8$ & 0.53 \\
Day 3 E2 (pg/ml) & $58.7 \pm 34.5$ & $49.4 \pm 30.3$ & 0.32 \\
AMH (ng/ml) & $0.7 \pm 0.1$ & $0.6 \pm 0.1$ & 0.64 \\
No of previous COH trial & $1.4 \pm 0.7$ & $1.4 \pm 0.6$ & 0.86 \\
\hline
\end{tabular}

antagonist/letrazole $(A L)$ protocol

The results of $\mathrm{COH}$ between MDL protocol versus $\mathrm{AL}$ protocol are shown in Table II. Duration of stimulation (10.2 \pm 2.3 vs. $7.6 \pm 2.2 ; \mathrm{p}=0.001)$, total gonadotropin dose (IU) (4589 \pm 1416 vs. $3088 \pm 1289 ; \mathrm{p}=0.001)$, peak E2 (pg/ml) level (1093 \pm 916 vs. $373 \pm 192 ; \mathrm{p}=0.004)$ and endometrial thickness on OPU day $(12.6 \pm 0.9 \mathrm{vs.}$ $9.3 \pm 1.5 ; \mathrm{p}=0.002$ ) were significantly lower in the $\mathrm{AL}$ 
group. There is no cycle cancellation was detected in the MDL group whereas statistically signicant higher rates of cycle cancellation $(35.7 \%, \mathrm{p}<0.001)$ was detected in the AL group.

Table II: The Controlled Ovarian Hyperstimulation (COH) response of the MDL and AL protocols.

\begin{tabular}{|c|c|c|c|}
\hline \multicolumn{4}{|l|}{ COH response } \\
\hline Variable & $\begin{array}{l}\text { MDL } \\
(n=27)\end{array}$ & $\begin{array}{l}\text { AL } \\
(n=28)\end{array}$ & $P$ \\
\hline Duration of stimulation (d) & $10.2 \pm 2.3$ & $7.6 \pm 2.2$ & $0.001 *$ \\
\hline Total gonadotropin dose (IU) & $4589 \pm 1416$ & $3088 \pm 1289$ & $0.001 *$ \\
\hline Peak E2 (pg/ml) & $1093 \pm 916$ & $373 \pm 192$ & $0.004^{*}$ \\
\hline \multicolumn{4}{|l|}{ Endometrial thickness on } \\
\hline day of OPU & $12.6 \pm 0.9$ & $9.3 \pm 1.5$ & $0.002 *$ \\
\hline Total cancellation rate $(\%)$ & 0 & $35.7(10 / 28)$ & $<0.001 *$ \\
\hline \multicolumn{4}{|l|}{ Cause of cancellation } \\
\hline Poor ovarian response & 0 & $14.2(4 / 28)$ & $<0.001 *$ \\
\hline After oocyte retrieval & 0 & $21.4(6 / 28)$ & $<0.001 *$ \\
\hline
\end{tabular}

$*_{p}<0.05$ : statistically significant

Cycle outcomes are shown in Table III. Number of retrieved oocytes $(3.7 \pm 2.9$ vs. $2.7 \pm 2.2)$, number of transferred embryos $(1.4 \pm 0.5$ vs. $1.4 \pm 1.9)$, clinical pregnancy rate $(3 / 27 ; 11.1 \%$ vs. $2 / 28 ; 7.1 \%)$ and implantation rate $3 / 368.3 \%$ vs. $2 / 229.1 \%$ ) were statistically similar in both groups.

Table III: Invitro Fertilization outcome of the MDL and AL protocols.

\begin{tabular}{llll}
\hline $\begin{array}{l}\text { Outcome of IVF } \\
\text { Variable }\end{array}$ & $\begin{array}{l}\text { MDL } \\
(\mathbf{n}=\mathbf{2 7})\end{array}$ & $\begin{array}{l}\text { AL } \\
(\mathbf{n}=\mathbf{2 8})\end{array}$ & $\boldsymbol{P}$ \\
\hline No of retrieved oocytes & $3.7 \pm 2.9$ & $2.7 \pm 2.2$ & 0.21 \\
No of mature oocytes & $2.8 \pm 2.1$ & $2.1 \pm 2.0$ & 0.27 \\
No of 2-pronuclei ooytes & $3.0 \pm 2.0$ & $2.1 \pm 2.4$ & 0.32 \\
Fertilization rate (\%) & 80.1 & 66.2 & 0.34 \\
No of embryos transferred & $1.4 \pm 0.5$ & $1.4 \pm 1.9$ & 0.98 \\
Clinical pregnancy rate per & & & \\
cycle attempt (\%) & $3 / 27(11.1)$ & $2 / 28(7.1)$ & 0.60 \\
Implantation rate (\%) & $3 / 36(8.3)$ & $2 / 22(9.1)$ & 0.92 \\
\hline
\end{tabular}

\section{DISCUSSION}

The results of this randomized prospective study showed that the days of stimulation and total gonadotropin dose were lower in the AL protocol compared to MDL protocol, however clinical pregnancy rates were similar in both protocol. Endometrial thickness were lower in the AL protocol and showed that lower endometrial thickness is not affect clinical pregnacy rate.

Aromatization of androgens to estrogens inhibition induces a reduction in circulating estrogen levels, as a result hypothalamic- pituitary axis escape from estrogenic negative feedback ${ }^{(13)}$. Hence FSH secretion is increased, and augmentation follicular sensitivity to FSH was observed. Aromatase inhibitors are widely used in assisted reproduction techniques according to this physiopathologic mechanism. Goswami et al. compared agonist protocol versus AL protocol, Garci Velasco et al. and Ozmen et al. in the study of comparison antagonist protocol versus AL protocol demonstrated that the addition of letrazole induce lower cancellation rates and higher pregnancy rate (14-16).

Schoolcraft et al compared 534 POR patients with Microdose Flare (MF) and AL protocol ${ }^{(17)}$. In $\mathrm{AL}$ group, $2.5 \mathrm{mg}$ letrazole was administered on day 3-7 of the cycle, there were similar result in mean female age, fertilization rate, number of transferred embryo and embryo scores. Peak E2 level was lower in the AL group whereas ongoing pregnancy rates were higher in the ML group than the AL group (52\% vs. 37\%).

Yarali et al compared antagonist/letrazole protocol with MF protocol(18). They demonstrated that doses of gonadotropin, duration of stimulation, serum E2 level on day of hCG and number of retrieved oocytes were significantly lower in the AL protocol compared with MF protocol. However fertilization rates and at least one top- quality embryo were higher in the $\mathrm{AL}$ protocol. Implantation rates were higher in the AL protocol (14,5\% vs. 9.8\%).

Davar et al compared GnRH antagonist /letrazole protocol with microdose GnRH agonist protocol(19). Days of stimulation, mean gonadotropin dose, metaphase II oocyte number, serum E2 level on day of HCG, serum estrogen level and number of good quality embryos were higher in the MDL group unlike our study. Clinical pregnancy rates and implatation rates were higher in the MDL group but these were not statictically significant whereas cancelled cycle rates were higher in the GnRH antagonist/letrazole group compared with MDL.

Mohsen and Din reported a comparison between MF protocol with AL protocol that performed 60 patients with diagnosis of $\mathrm{POR}^{(20)}$. In the AL group, $2.5 \mathrm{mg}$ letrazole was given on day 2-6 of the cycle and on day 7; hMG was started. Hormonal features and 
clinical pregnancy rates were similar results statistically (13.3\% vs. $16.6 \%)$. However gonadotropin dose and duration of stimulation were lower significantly in the AL group.

In conclusion, Although AL protocol is not superior to MDL protocol in poor ovarian response patients, it may be used as an alternative protocol. Despite endometrial thickness was lower in the AL group, clinical pregnancy rates were not affected. Further powerful randomized studies in large population are needed to assess the optimum $\mathrm{COH}$ protocol in poor responders

\section{REFERENCES}

1. Tarlatzis BC, Zepiridis L, Grimbizis G, Bontis J. Clinica management of low ovarian response to stimulation for IVF: a systematic review. Hum Reprod Update 2003; 9: 61- 76

2. Ferraretti AP, La Marca A, Fauser BC, Tarlatzis B, Nargund G, Gianaroli L; ESHRE working group on Poor Ovarian Response Definition. ESHRE consensus on the definition of 'poor response' to ovarian stimulation for in vitro fertilization: the Bologna criteria. Hum Reprod. 2011 Jul; 26(7): 1616- 24. Epub 2011 Apr 19

3. Polyzos NP, Devroey P. A systematic review of randomized trials for the treatment of poor ovarian responders: is there any light at the end of the tunnel? Fertil Steril. 2011 Nov; 96(5): 1058- 61.e7.

4. Venetis CA, Kolibianakis EM, Tarlatzi TB, Tarlatzis BC Evidence-based management of poor ovarian response. Ann N Y Acad Sci. 2010 Sep;1205: 199- 206. doi: 10.1111/j.1749 6632.2010.05665.x. Review.

5. Kyrou D, Kolibianakis EM, Venetis CA, Papanikolaou EG, Bontis J, Tarlatzis BC. How to improve the probability of pregnancy in poor responders undergoing in vitro fertilization: a systematic review and meta-analysis. Fertil Steril. 2009 Mar; 91(3): 749- 66. doi: 10.1016/j.fertnstert.2007.12.077. Epub 2008 Jul 21. Review.

6. Vollenhoven B, Osianlis T, Catt J. Is there an ideal stimulation regimen for IVF for poor responders and does it change with age? J Assist Reprod Genet. 2008 Nov-Dec; 25(11-12): $523-$ 9. doi: 10.1007/s10815-008-9274-6. Epub 2008 Nov 4.

7. Fábregues F, Peñarrubia J, Creus M, Manau D, Casals G, Carmona F, Balasch J. Transdermal testosterone may improve ovarian response to gonadotrophins in low-responder IVF patients: a randomized, clinical trial. Hum Reprod. 2009 Feb; 24(2): 349- 59. Epub 2008 Dec 3.
8. de Ziegler D, Streuli I, Meldrum DR, Chapron C. The value of growth hormone supplements in ART for poor ovarian responders. Fertil Steril. 2011 Nov; 96(5): 1069- 76.

9. Papanikolaou EG, Polyzos NP, Humaidan P, Pados G, Bosch E, Tournaye H, Tarlatzis B. Aromatase inhibitors in stimulated IVF cycles. Reprod Biol Endocrinol. 2011 Jun 21; 9: 85.

10. Jovanovic VP, Kort DH, Guarnaccia MM, Sauer MV, Lobo RA. Does the addition of clomiphene citrate or letrazole to gonadotropin treatment enhance the oocyte yield in poor responders undergoing IVF? J Assist Reprod Genet. 2011 Nov; 28(11): 1067- 72. Epub 2011 Oct 12.

11. Garcia-Velasco JA. The use of aromatase inhibitors in in vitro fertilization. Fertil Steril. 2012 Dec; 98(6): 1356- 8. doi: 10.1016/j.fertnstert.2012.09.042. Epub 2012 Oct 11. Review.

12. Miller PB, Parnell BA, Bushnell G, Tallman N, Forstein DA, Higdon HL 3rd, Kitawaki J, Lessey BA. Endometrial receptivity defects during IVF cycles with and without letrozole. Hum Reprod. 2012 Mar; 27(3): 881- 8. doi: 10.1093/humrep/ der452. Epub 2012 Jan 13.

13. Requena A, Herrero J, Landeras J, Navarro E, Neyro JL, Salvador C, Tur R, Callejo J, Checa MA, Farré M, Espinós JJ, Fábregues F, Graña-Barcia M; Reproductive Endocrinology Interest Group of Spanish Society of Fertility. Use of letrozole in assisted reproduction: a systematic review and meta-analysis. Hum Reprod Update. 2008 Nov-Dec;14(6): 571- 82. doi: 10.1093/humupd/dmn033. Epub 2008 Sep 23.

14. Goswami SK, Das T, Chattopadhyay R, Sawhney V, Kumar J, Chaudhury K, Chakravarty BN, Kabir SN. A randomized single-blind controlled trial of letrozole as a low-cost IVF protocol in women with poor ovarian response: a preliminary report. Hum Reprod. 2004 Sep; 19(9): 2031- 5. Epub 2004 Jun 24.

15. Garcia-Velasco JA, Moreno L, Pacheco A, Guillén A, Duque L, Requena A, Pellicer A. The aromatase inhibitor letrozole increases the concentration of intraovarian androgens and improves in vitro fertilization outcome in low responder patients: a pilot study. Fertil Steril. 2005 Jul; 84(1): 82- 7.

16. Ozmen B, Sönmezer M, Atabekoglu CS, Olmus H. Use of aromatase inhibitors in poor-responder patients receiving GnRH antagonist protocols. Reprod Biomed Online. 2009 Oct;19(4): 478- 85 .

17. Schoolcraft WB, Surrey ES, Minjarez DA, Stevens JM, Gardner DK. Management of poor responders: can outcomes be improved with a novel gonadotropin-releasing hormone antagonist/letrozole protocol? Fertil Steril. 2008 Jan;89(1):1516. Epub 2007 May 4.

18. Yarali H, Esinler I, Polat M, Bozdag G, Tiras B. Antagonist/ letrozole protocol in poor ovarian responders for 
intracytoplasmic sperm injection: a comparative study with the microdose flare-up protocol. Fertil Steril. 2009 Jul; 92(1): 231- 5. Epub 2008 Aug 3.

19. Davar R, Oskouian H, Ahmadi S, Firouzabadi RD. GnRH antagonist/letrozole versus microdose GnRH agonist flare protocol in poor responders undergoing in vitro fertilization.
Taiwan J Obstet Gynecol. 2010 Sep; 49(3): 297- 301.

20. Mohsen IA, El Din RE. Minimal stimulation protocol using letrozole versus microdose flare up GnRH agonist protocol in women with poor ovarian response undergoing ICSI. Gynecol Endocrinol. 2013 Feb; 29(2): 105- 8. doi: 10.3109/ 09513590.2012.730569. Epub 2012 Nov 7. 